CHEMISTRY IN THE AGRICULTURAL COLLEGE

Professor Copeland in a recent article in ScIENCE" 1 on "Botany in the Agricultural College" states as a minor point that much of the chemistry taught in these institutions is not basic to work in agriculture.

It may be interesting to note in this connection that we have found in this laboratory that it is possible to give freshmen, in a required course in chemistry, work which has relation to agriculture and seems to be of interest to them.

The work is synthetic rather than analytic or descriptive in character, and consists, in part, in preparation from the original sources of the following materials: superphosphate, ammonium sulfate (from gas liquor), high grade muriate and sulfate of potash, as well as the sulfate of potash-magnesia from crude salts, arsenate of lead, lime-sulfur, Bordeaux mixture, Paris green and various emulsions.

A student spends one or more two-hour laboratory periods on one preparation, often using the product of one day's work to make a second substance. For example, copper sulfate is made from metallic copper, and at a following exercise Bordeaux mixture and Paris green are made from the copper salt. Similarly lead nitrate is made from the oxid before the nitrate is used to prepare the arsenate of lead.

Many of these preparations, in the making, furnish excellent opportunities to illustrate the principles of mass-action and some phases of colloidal chemistry.

\section{A. Peters}

Massachusetts Agricultural College, Department of General and Agricultural Chemistry

THE RENOUNCING OF HONORARY DEGREES

To the Editor of Science: In your issue of October 2, I notice certain German professors have stated their intention of renouncing the honorary degrees conferred upon them by British universities. If they imagine they can do this they are, as regards Cambridge,

1 September 18, 1914, page 401. imagining a vain thing. Our statutes, which are acts of parliament, give no power, even to the authorities of the university itself, to take away honorary degrees.

The utmost the German professors can do is to cease to use them, but they will still remain honorary doctors of Cambridge. They will go down to the tomb with this indelible stain upon their names.

\section{Christ's College, CAMBRIDGE}

\section{SCIENTIFIC BOOKS}

Telegraphy. By the late Sir W. H. Preece, K.C.B., F.R.S., and Sir J. Sivewright, M.A., K.C.M.G. Revised and partly rewritten by W. Llewelly Preece. London and New York, Longmans, Green and Co., 1914. 422 pages, 269 illustrations. Price $\$ 2.25$ net.

This interesting volume in the Text-Book of Science Series is a thorough revision of a smaller volume of 300 pages by the same two authors published by Longmans, Green \& Co. in 1876. Although the original volume passed through nine editions, its contents remained almost unchanged. At that time, the book was practically the only one on the subject of telegraphy in Great Britain available for operators and artisans employed in the British post-office system. Great changes have naturally taken place in that system during the 38 years which have passed since the book first made its appearance. The new book has, for instance, to include telephones and telephony, neither of which is referred to in the original edition. On the other hand, it has been necessary to exclude, for want of space, some of the subjects dealt with in the original volume.

In clearness and simplicity of statement, it would be difficult for the new edition to improve upon the old. All the writings of the late Sir William Preece were signalized by their directness and lucidity. His collaborator, Sir James Sivewright, was entitled to a like share of praise for his literary presentations. Between them they wrote a volume that remained, during a generation, a standard for 